\title{
電力流通設備の防食技術の開発とその普及*
}

\author{
市場幹之* \\ * 東京電力ホールデイングス株式会社 経営技術戦略研究所
}

\section{Development and Penetration of Technologies for Preventing Corrosion of Electric Power Distribution Facilities*}

\author{
Mikiyuki Ichiba* \\ * $R \&$ D Dept., Tokyo Electric Power Company Holdings Inc.
}

\begin{abstract}
The structure of the electric power business has been undergoing a major transformation in recent years. Japan's vertically integrated electric power supply system is now going through a historical paradigm shift with respect to the wide-area operation of power transmission lines, complete liberalization of electricity retailing, and separation of power generation and transmission. These trends also affect the issue of preventing the corrosion of power distribution facilities, making efforts to maintain the facilities and to estimate their service life and damage risk all the more important. This paper focuses on the issue of preventing the corrosion of utility poles and outside steel structure facilities that account for a large portion of the installed electric power distribution network. It describes the present status of performance evaluation tests conducted on prestressing steel tendons used in concrete poles (PC steel) and heavy duty coatings as well as the activities of related academic societies.
\end{abstract}

Key words : power distribution facility, concrete pole, hydrogen embrittlement, FIP, JSCE S 1201, ammonium thiocyanate, corrosion, pole transformer, PC steel, salt damge environment, exposure test, corrosion map, heavy duty coating

\section{1.は じめに}

近年，電気事業の体制は大きな変貌を遂げつつある. 戦後構築された電力供給体制は, 当時の米国の電気事業 制度を模した垂直統合型の体制で，地域独占と総括原価 方式で電力会社の経営基盤を担保し電力供給を促すもの であった。

垂直統合型の電力供給体制は電力システム改革の途上 にあり, 送電線の広域運用, 小売全面自由化, 発送電分 離といった歴史的なパラダイムシフトを迎えている ${ }^{1)}$. 従来の電力事業は, Fig. 1 に示すように「発電事業」, 「送配電事業」,「小売電気事業」に再編される。「送配電 事業」は 2020 年の法的分離を含め高い中立性が求めら れている。この変化は,「送配電事業」を支える電力流 通設備の保全や関連する腐食防食課題にも大きく影響す る. 設備管理者は合理的な設備形成や維持管理と設備寿 命や損傷リスクに関する取り組みが求められる.

筆者らは腐食防食学会を中心に電力流通設備の経年劣 化事例や対策を報告してきた ${ }^{2-12)}$ 。建設時は想定してい なかった経年劣化事象や品質管理としての試験評価法の 課題も顕在化している．本稿では筆者が関与した電力流 通設備の腐食防食課題への取り組みや学協会と連携した 活動について紹介する。

\section{2. 電力流通設備と供給体制の変化}

垂直統合型の電力供給体制のおける電力供給の流れを Fig.2 に示す。ここでは発電所から消費者に送り届ける

\footnotetext{
* ₹ 230-8510 横浜市鶴見区江ヶ崎町 4-1 (4-1, Egasaki-cho, Tsurumi-ku,
} Yokohama, 230-8510 Japan)
設備を電力流通設備としている。電力流通設備は，主に 発電所や変電所をつなぐ送電, 送電からの電圧を降圧す るなど電圧を変化させる変電, 変電と需要家をつなぐ配 電の 3 部門から構成される。各部門は設備の広がりが異 なり, 変電所は点, 送電網は線, 配電網は面に例えられ る．部門間の設備量も 3 桁以上の差異があり，当社の例 では変電設備が約 1600 箇所，送電鉄塔が約 45000 基, 電柱が約 580 万基である。これらの設備は高度成長期に 多くが形成され，経済成長の鈍化に伴い設備更新の機会 は減少傾向にある，島国である日本の峳しい自然環境に

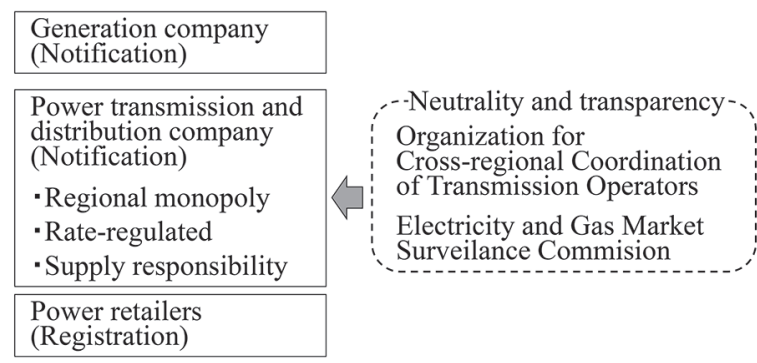

Fig. 1 Power transmission and distribution business and the business classification after the domestic electricity system reform

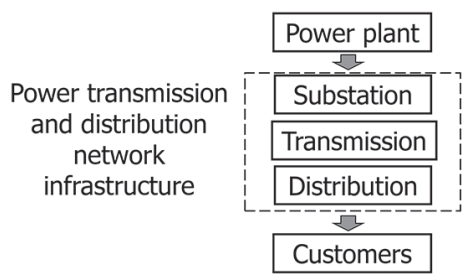

Fig. 2 Vertically integrated power supply system 
曝される電力流通設備の腐食対策を中心とした設備保全 は重要な経営課題である.

電力流通設備の形成や保全は, 地域独占と総括原価方 式に基づく費用積算により電力の安定供給とお客様への 安全安心を指向している。電力システム改革以降の「送 配電事業」においても地域独占と総括原価方式は継承さ れるが，その実態は大きく恋化する. 電力流通設備は公 的インフラとなり，2015 年に電力市場の監視を目的に電 力事業者から独立した電力取引監視等委員会が設立され た ${ }^{1}$. 託送料金は電力取引監視等委員会の審査を経て国 の認可により決定される。電力会社が積算した託送料金 に対する審査や認可の過程では, 従来の電力安定供給と 安全安心に加えて電力流通コストの透明化や徹底した削 減が強く求められる。このため将来的な保全費用に直結 する設備の性能や品質に対する管理はより重要となる. さらに, 審査の中立性や透明性の観点から設備に要求さ れる品質や性能は標準化された規格や試験で規定するこ とが望まれる．電力流通コストの削減では設備仕様の共 通化や統合も要求される. 設備製造者が独自に実施して いた性能試験を，設備管理者を含めて実施可能な中立的 な試験評価技術とすることなども必要となる．現行の規 格で品質の規定が難しい場合には, 品質管理精度の向上 を目的とした新たな試験評価技術の確立が必要となる。

\section{3. 電柱と $\mathrm{PC}$ 鋼材の水素脆化}

配電設備は電力流通設備の中で最も消費者に近く，か つ数量が大きい設備である. 電柱は架空配電機材や電線 が装柱される重要な設備で数量も膨大である，電柱を例 に腐食防食課題への取り組みを紹介する。

電柱には一般的にプレストレストコンクリート柱が用 いられる。コンクリート柱内の鉄筋には高強度である $\mathrm{PC}$ 鋼材が用いられる。コンクリート柱の製造工程を Fig.3に示す．鉄筋籠を型枠に設置し，型枠内で緊張筋 となる PC 鋼材に引張応力を付与した状態で固定する. 型枠にコンクリートを注入し, 遠心成型, 養生を行う。 コンクリートと鉄筋の付着を確保した後に PC 鋼材の緊 張を解放し, コンクリート柱にプレストレスを付与する. 遠心成型で脱水して製造されるためコンクリート柱の水 セメント比は $20 \sim 40 \%$ と小さく ${ }^{13)}$, 経年による中性化

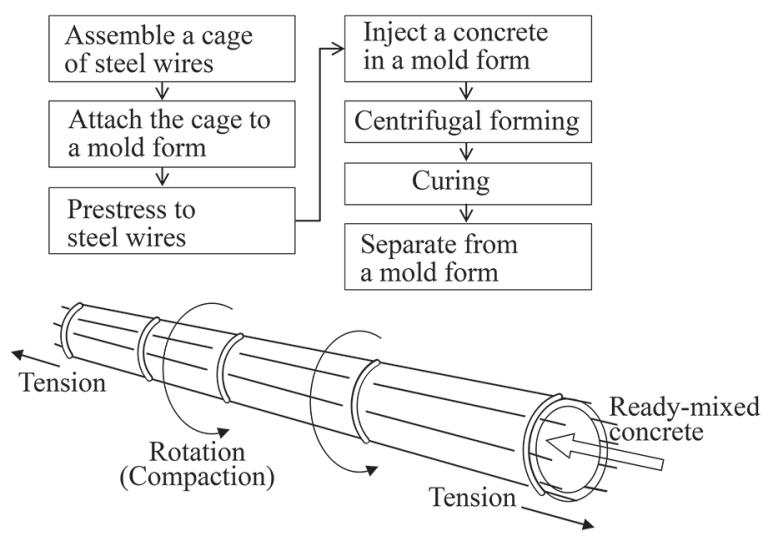

Fig. 3 The manufacturing process of the pre-stressed concrete poles
はほとんど進行しない ${ }^{14)}$.このためコンクリートにひび 割れなどの損傷がない限り，柱内部は高い $\mathrm{pH}$ が保たれ 内部鉄筋の腐食が長期にわたり抑制される。コンクリー ト柱はコンクリートにより圧縮強度, 内部の PC 鋼材に よるプレストレスで鞎性が付与される。このため高荷重 が加わると柱体がたわみコンクリート表面にはひびが発 生し, 荷重が除荷されるとプレストレスによりひびが閉じ る. JIS A 5373 : 2010 では除荷後のひび巾として 0.05 mm 以下であることが規定されている ${ }^{15)}$. 台風などで過大な 荷重がかかるとひび割れが生じ雨水が侵入する．PC 鋼 材の周囲の $\mathrm{pH}$ が低下すると鋼材は腐食を始める ${ }^{16)}$. プ レストレスを付与するため高い応力がかかった状態で $\mathrm{PC}$ 鋼材のような高強度鋼に腐食反応で生じた微量の水 素が鋼材に侵入すると，靶性が失われ脆化により破断を 生じる可能性がある ${ }^{17)}$.この現象は水素脆化と呼ばれ, $\mathrm{PC}$ 鋼材を用いた一部のコンクリート柱で水素脆化によ る鉄筋破断が報告されている ${ }^{18)}$. 腐食のみによる鋼材の 破断は減肉によるため進行が遅いが，水素脆化による破 断は突然生じる。このためコンクリート柱の設備信頼性 の維持や保全負荷軽減において, PC 鋼材の水素脆化感 受性を安全側で評価する品質管理試験法の確立は重要で ある。

\section{4. コンクリート柱内の PC 鋼材の品質管理試験}

プレキャストプレストレストコンクリート製品を規定 した JIS A 5373 では，2010 年の改訂時にコンクリート柱 に使用される $\mathrm{PC}$ 鋼材の応力腐食割れに対する耐久性能 の重要性を考慮した改訂がなされている ${ }^{15)}$. 受渡当事者 間の協定として，「ポール類に使用する PC 鋼材は，受 渡当事者間で協議して応力腐食割れに対する耐久性能が 確認されたものを使用する.」の記載が追加された。こ こに記載された「応力腐食割れ」は水素脆化に起因した 遅れ破壊を意味する．PC 鋼材が水素脆化を生じる条件 は, 鋼材強度, 応力, 鋼中水素濃度の三つの因子が揃う ことである，品質管理に用いる水素脆化評価試験では, 対象鋼材や使用状態が特定されるため, 鋼材強度と負荷 応力は限定される.このため水素脆化を促進するために は鋼中水素濃度を高めて試験を行う必要がある。

$\mathrm{PC}$ 鋼材の品質管理を目的とした代表的な水素脆化評価 試験方法は, 公的試験規格として 1980 年に国際プレスト レストコンクリート連盟(FIP : Fédération Internationale de la Précontrainte) で規格化され ${ }^{19)}$, その後 ISO 15630 に採 用されている ${ }^{20)}$. 日本国内では通称 FIP 試験として知られ ている. FIP 試験装置の概要を Fig.4に示す。この試験方

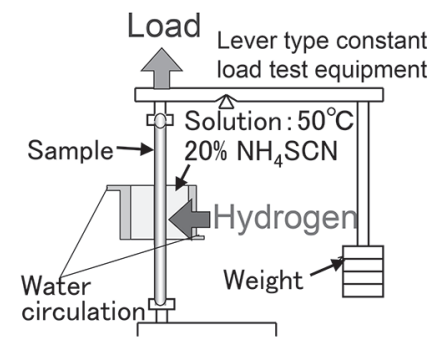

Fig. 4 The schematic diagram of FIP test equipment 
法は荷重が安定する定荷重試験と，簡便な浸漬法を組み 合わせた方法である. FIP 試験の浸漬条件は 20 mass\%チ オシアン酸アンモニウム溶液, 温度 $50^{\circ} \mathrm{C}$ である. チオシア ン酸アンモニウムは, 浸漬法の中では塩酸より高い鋼中水 素濃度が得られ ${ }^{21)}$, 亜ヒ酸などの水素吸蔵促進薬品 ${ }^{22)}$ に 比較し扱いやすいという特徵がある. 評価は $200 \mathrm{~h}$ を試験 打切り時間として試験材の破断時間で行う ${ }^{19)}$. この試験で 得られる破断時間から実環境での破断寿命を直接算出する ことはできない。しかし，鋼材間の耐水素脆性の相対評価 はある程度可能であることから，PC 鋼材を製品状態で評 価する水素脆化評価試験法として広く普及している ${ }^{20), 23)}$.

\section{FIP 試験への取り組みと活用}

\subsection{FIP 試験の技術的な課題}

従来の設備仕様は性能規定を指向していたことからメー カー間で構造や使用材料が異なり，使用材料に適した品 質管理試験がメーカー独自に行われる傾向があった。電力 システム改革を背景に近年では設備仕様に付帯する構造 や使用材料は共通化される傾向にある。仕様書内では使 用材料と付帯する品質管理試験法や閾值が規定される. 仕様に用いる品質管理試験法は実施機関による測定誤差 を小さくする必要があり試験再現性が要求される.

品質管理に用いる FIP 試験の技術課題の一つが 12 回の 試験繰り返し数を必要とする試験再現性の向上である ${ }^{19,23)}$. 同一仕様の PC 鋼材の鉄筋で，実施機関により FIP 試験で の平均破断時間が 1 オーダー以上異なる例が報告されてい る ${ }^{24)}$. メーカーが独自に PC 鋼材の品質管理を行う場合, 試験再現性の欠如は各社異なる䦭值を設定し, 試験繰り 返し数を増やすことで対応できる。一方，機材や材料仕 様の共通化では, 同一規格の PC 鋼材の性能を仕様書で 明確に規定し，統一した䦨值で品質管理を行う。このた め複数の実施機関での試験再現性の向上や試験機会内の バラツキの抑制が課題となる. 試験中の溶液 $\mathrm{pH}$ の変化, 比液量, 溶存酸素などの基本的な試験条件の破断時間に 対する影響やメカニズムを解明することが必要となる ${ }^{19)}$.

定荷重試験である FIP 試験では荷重の繰り返し再現性 は確保される。試験再現性の欠如は試験時の水素吸蔵に 起因している.このため, 水素吸蔵を支配するチオシアン 酸アンモニウム溶液中での鋼材腐食反応を解明して, 試験 条件を最適化し試験再現性を向上することが重要となる.

\subsection{FIP 試験環境中での鋼材腐食機構}

FIP 試験の主要条件が決定された当時の鋼材の腐食反 応機構として, pH が 7 未満において (1) 式のアノード反 応と (2)式のカソード反応が示されている ${ }^{19)}$.

$$
\begin{aligned}
& \mathrm{Fe} \rightarrow \mathrm{Fe}^{2+}+2 \mathrm{e}^{-} \\
& 2 \mathrm{H}^{+}+2 \mathrm{e}^{-} \rightarrow \mathrm{H}_{2}
\end{aligned}
$$

溶液 $\mathrm{pH}$ は試験中 $\mathrm{pH}$ 4 7 を示す.（2) 式の反応は単 純な $\mathrm{H}^{+}$の還元反応で溶液の $\mathrm{H}^{+}$濃度に吸蔵水素量が依存 することを示唆する. しかし, pH 4〜 7 の FIP 試験溶液 が $\mathrm{pH} 2$ の塩酸溶液より水素吸蔵量が大きいことと整合 しない ${ }^{21)}$.

(2) 式の反応が提案された背景には $\mathrm{SCN}^{-}$の高い安定性 が関係する. $\mathrm{SCN}^{-}$は-S-C $\equiv \mathrm{N}$ の構造で $\mathrm{CN}$ 間の 3 重結 合は一般に安定である. $\mathrm{SCN}^{-}$が $\mathrm{S}^{0}$ と $\mathrm{CN}^{-}$に分解する反
応は，標準生成ギブスエネルギー $\Delta \mathrm{G}^{\circ}$ が $79.7 \mathrm{~kJ} / \mathrm{mol}$ で 進行しない ${ }^{27)}$. このため $\mathrm{NH}_{4} \mathrm{SCN}$ の関与するカソード 反応が提案されず，(2) 式の反応が FIP 試験環境でのカ ソード反応とされたものと推定される.

FIP 試験環境に浸漬した PC 鋼材の腐食減量および溶 液 $\mathrm{pH}$ の経時変化を Fig.5に示す ${ }^{25)}$. 図中 $($ ○)で示した 腐食減量は経時に伴い増加した。図中 $(\bigcirc)$ で示した浸漬 試験前の溶液 $\mathrm{pH}$ は 4.5 , 浸漬後 $24 \mathrm{~h}$ で $\mathrm{pH}$ は約 6.5 まで 上昇し, 鋼材の腐食が継続する $24 \mathrm{~h}$ 以降も $\mathrm{pH}$ は 6.5 付 近で一定であった.

浸漬後の試験材表面は，極初期から鉄酸化物と鉄硫化 物が生成し ${ }^{26)} ， 24 \mathrm{~h}$ 浸漬後で全面に $\mathrm{Fe} ， \mathrm{O}, \mathrm{S}$ を含む厚 さ1 2 $2 \mu \mathrm{m}$ の多孔質な黒色皮膜が, $196 \mathrm{~h}$ 浸漬後で厚さ 約 $40 \mu \mathrm{m}$ の FeS (Mackinawite) を含む緻密な内層とポー ラスな外層の黒色皮膜を生成した ${ }^{25)}$.

$\Delta \mathrm{G}^{\circ}<0$ となる $\mathrm{CN}^{-}$の分解を伴うカソード反応として (3) 式のカソード反応を新たに示した ${ }^{25), 28)}$.

$$
\mathrm{SCN}^{-}+2 \mathrm{H}_{2} \mathrm{O}+\mathrm{H}^{+}+2 \mathrm{e}^{-} \rightarrow \mathrm{S}^{2-}+\mathrm{H}_{2}+\mathrm{CO}_{2}+\mathrm{NH}_{3}
$$

(3) 式の $\Delta \mathrm{G}^{\circ}$ は- $184.2 \mathrm{~kJ} / \mathrm{mol}$ で, 鉄電極表面の $\mathrm{H}^{+}$の単 純な還元反応の $\Delta \mathrm{G}^{\circ}$ である-78.9 $\mathrm{kJ} / \mathrm{mol} よ り$ 小い ${ }^{27)}$. (3) 式のカソード反応は安定とされる $\mathrm{SCN}^{-}$の分解を伴う 反応である。 $\mathrm{CN}$ 結合が切断し $\mathrm{NH}_{3}$ を生成する腐食反応 は, 反応に伴う微量の $\mathrm{NH}_{3}$ や $\mathrm{NH}_{4}{ }^{+}$を検出して実証した。 $\mathrm{NH}_{4} \mathrm{SCN}$ 溶液中では高濃度の $\mathrm{NH}_{4}{ }^{+}$により微量の $\mathrm{NH}_{3}$ を 検出できない. $\mathrm{SCN}^{-}$のみに $\mathrm{N}$ を含有する $\mathrm{NaSCN}$ 溶液 の腐食試験後の溶液をイオンクロマトグラフで分析して $\mathrm{NH}_{4}{ }^{+}$の生成を確認した結果を Fig.6に示す。腐食試験条

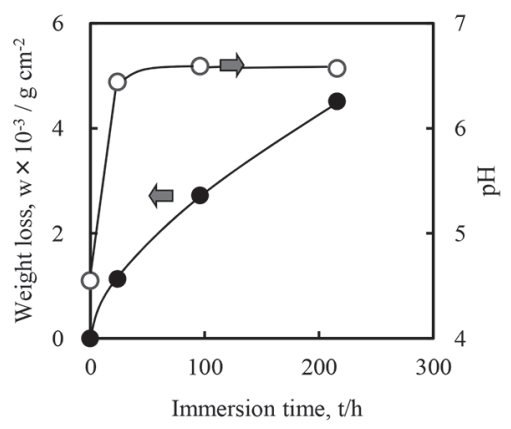

Fig. 5 Weight loss of specimens and $\mathrm{pH}$ of test solutions during immersion tests in $20 \% \mathrm{NH}_{4} \mathrm{SCN}$ at $50{ }^{\circ} \mathrm{C}$.

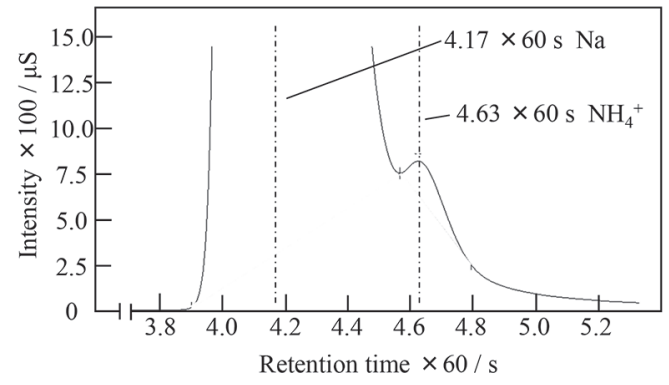

Fig. 6 Semi-quantitative analysis of $\mathrm{NH}_{4}{ }^{+}$concentration in the solution after the 24 -h immersion test by ion chromatography. Immersion conditions: $2.73 \mathrm{~mol} / \mathrm{L} \mathrm{Na}$ $\mathrm{SCN}(\mathrm{pH} 4.2), 50^{\circ} \mathrm{C}$ and solution volume-to-specimen surface area of $10 \mathrm{ml} / \mathrm{cm}^{2}$. 
件は 20 mass\% $\mathrm{NH}_{4} \mathrm{SCN}$ と同モル濃度の $\mathrm{NaSCN}$ 溶液, 溶液 $\mathrm{pH}$ は酢酸系の緩衝溶液で 20 mass $\% \mathrm{NH}_{4} \mathrm{SCN}$ の初 期とほぼ同 $\mathrm{pH}$ の 4.2 , 溶液温度 $50{ }^{\circ} \mathrm{C}$, 浸漬時間 $24 \mathrm{~h}$ で ある。緩衝溶液無添加の $\mathrm{NaSCN}$ 溶液中での浸漬試験で は, 溶液 $\mathrm{pH}$ は浸漬開始直後に 7.5 程度まで急激に上昇 しほとんど腐食は生じない ${ }^{30)}$.

(3)式のカソード反応に関する分極曲線を Fig.7 に示す ${ }^{30)}$. 試験浴は Fig.6 で用いた pH4.2 の NaSCN 溶液を基準に, 緩衝溶液を低減 $(\mathrm{pH}$ 5.9) および無添加とした 3 種の $\mathrm{NaSCN}$ 溶液を用いた。浸漬電位から $-1.0 \mathrm{~V}$ vs. SCE 付近 の領域でのカソード電流密度は溶液 $\mathrm{pH}$ の低下に伴い増 加する。この領域での $\mathrm{H}^{+}$の供給は, 緩衝溶液とは無関 係な水の解離平衡に依存した $\mathrm{H}^{+}$の供給に対して, 緩衝 溶液の酢酸からの $\mathrm{H}^{+}$供給に伴う腐食電流密度が約 30 100 倍大きな值を示す。（3）式のカソード反応は溶液から の $\mathrm{H}^{+}$供給に依存する.

$\mathrm{NH}_{4} \mathrm{SCN}$ は溶液中で $\mathrm{NH}_{4}{ }^{+}$と $\mathrm{SCN}^{-} に$ 完全に解離してい る. また, $\mathrm{NH}_{4}{ }^{+}$は溶液中で(4) 式に示す加水分解を生じ る.

$\mathrm{NH}_{4}^{+}+\mathrm{H}_{2} \mathrm{O} \rightleftarrows \mathrm{NH}_{3}+\mathrm{H}_{3} \mathrm{O}^{+}$

アンモニアの塩基解離定数 $\mathrm{pK}_{\mathrm{b}}$ は $25{ }^{\circ} \mathrm{C}$ で 4.75 であり (4) 式の平衡は大きく左に寄っている. 溶液中の $\left[\mathrm{NH}_{3}\right]$ と $\left[\mathrm{H}^{+}\right]$は $\left[\mathrm{NH}_{4}^{+}\right]$の $10^{-4}$ 以下の非常に小さな值となり腐食 反応による $\mathrm{H}^{+}$の消費や $\mathrm{NH}_{3}$ の生成は溶液 $\mathrm{pH}$ を急激に 上昇させる. FIP 試験環境中では $\mathrm{H}^{+}$の消費による $\mathrm{pH}$ 上 昇により腐食反応速度は低下するが，(4) 式の $\mathrm{NH}_{4}{ }^{+}$の解 離による $\mathrm{H}^{+}$の供給により継続する.

気相の変化は浸漬初期から $\mathrm{H}_{2}$ が発生し $\mathrm{O}_{2}$ が消費され る ${ }^{25)}$.（3) 式と同時に進行するカソード反応が (5) 式の溶 存酸素の還元反応である.

$$
\mathrm{H}_{2} \mathrm{O}+1 / 2 \mathrm{O}_{2}+2 \mathrm{e}^{-} \rightarrow 2 \mathrm{OH}^{-}
$$

FIP 試験の主要条件が決定された当時，(5)式のカソー ド反応は $\mathrm{pH}$ が 7 以上の領域のカソード反応とされてい た ${ }^{19)}$.

(3) 式の反応は浸漬時の $\mathrm{FeS}, \mathrm{H}_{2}, \mathrm{NH}_{3}$ の生成と整合 している.

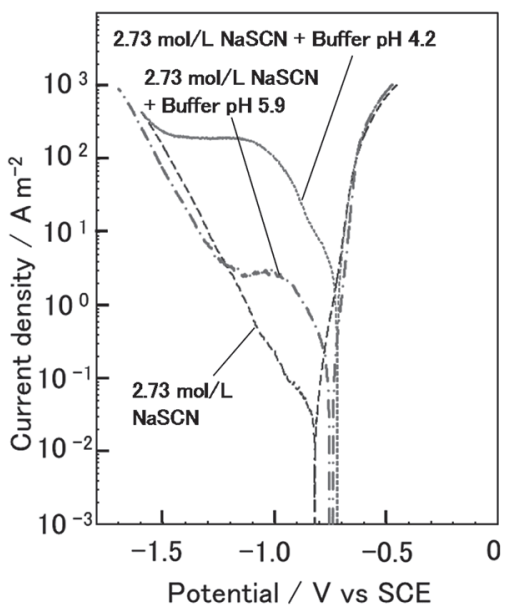

Fig. 7 Polarization curves measured for specimens immersed in various $\mathrm{pH}$ of $2.73 \mathrm{~mol} / \mathrm{L} \mathrm{NaSCN}$ solutions with or without $\mathrm{pH}$ buffer solutions at $50^{\circ} \mathrm{C}$ in an $\mathrm{Ar}$ deaeration atmosphere.

\subsection{FIP 試験での水素吸蔵}

FIP 試験時の鋼中水素濃度は経時に対してピークを示 す.引張り強度が $1400 \mathrm{MPa}$ 級の焼入れ焼き戻し $\mathrm{PC}$ 鋼 棒の例を Fig. 8 に示す. 鋼中水素濃度は浸漬後 $24 \sim 48 \mathrm{~h}$ で約 3.2 mass ppm まで上昇した後に低下に転じるが, $200 \mathrm{~h}$ でも 2.5 mass ppm の濃度を維持する ${ }^{13)}$.

本試験環境でのカソード反応は $\mathrm{SCN}^{-}$の分解を伴う (3) 式と (5) 式の溶存酸素の還元反応である、純酸素雲囲気 と脱気䨌囲気で FIP 試験環境に浸漬した PC 鋼材の鋼中 水素濃度はほぼ同濃度であった ${ }^{28)}$ 。溶存酸素の還元反応 に影響を与える酸素の有無により鋼中水素濃度は影響を 受けない. 水素吸蔵を支配するカソード反応は $\mathrm{SCN}^{-}$の 分解を伴う (3) 式の反応である.

水素吸蔵を支配する (3) 式の反応は, 鋼材表面に生成す る $\mathrm{FeS}$ を主体とする腐食皮膜により抑制される. Fig.8 で $200 \mathrm{~h}$ 経過時の試験材は鋼中水素濃度が低下傾向にある. 表面の腐食生成物を除去して再浸漬すると鋼中水素濃度 はピークに近い濃度まで再上昇する ${ }^{29)}$. $\mathrm{FeS}$ 皮膜は $\mathrm{pH}$ 上昇に伴い析出が促進され (3) 式の反応を抑制し, 鋼中 水素濃度の上昇は鈍化する。析出した $\mathrm{FeS}$ 皮膜は鋼中に 吸蔵した水素放出に対しては障壁効果を示さないため, 鋼中水素濃度は低下に転じる。 FeS 皮膜は成長に伴い割 れを生じ，腐食反応が割れ発生部で継続するため，鋼中 水素濃度は低下するものの, 試験期間中一定以上の濃度 が維持される ${ }^{28)}$.

\subsection{FIP 試験の試験再現性向上}

水素吸蔵量は $(3)$ 式の反応と $\mathrm{FeS}$ を主体とする腐食皮 膜の生成に支配される。いずれも溶液 $\mathrm{pH}$ の影響を大き く受けることから, 水素吸蔵を考える上で溶液 $\mathrm{pH}$ は重 要な因子である.

FIP 試験時の Fig.5 に示した溶液 $\mathrm{pH}$ の経時変化は (2) 式のカソード反応では説明できない，(1)，(3)，（5)式に 基づき浸漬試験時の溶液 $\mathrm{pH}$ を計算した結果を Table. 1 に示す ${ }^{30)}$. 溶液調製時の 20 mass $\% \mathrm{NH}_{4} \mathrm{SCN}$ 溶液の溶液 $\mathrm{pH}$ は, (4) 式に示した $\mathrm{NH}_{4}{ }^{+}$の加水分解で生じる $\mathrm{H}^{+}$( (4) 式では $\mathrm{H}_{3} \mathrm{O}^{+}$と表記 $) \mathrm{NH}_{3}$ からの計算結果と整合する。ま た，浸漬時の溶液 $\mathrm{pH}$ の急激な上昇と上昇の鈍化は，浸 漬後の $(3)$ 式のカソード反応による $\mathrm{H}^{+}$と $\mathrm{NH}_{3}$ の変化に

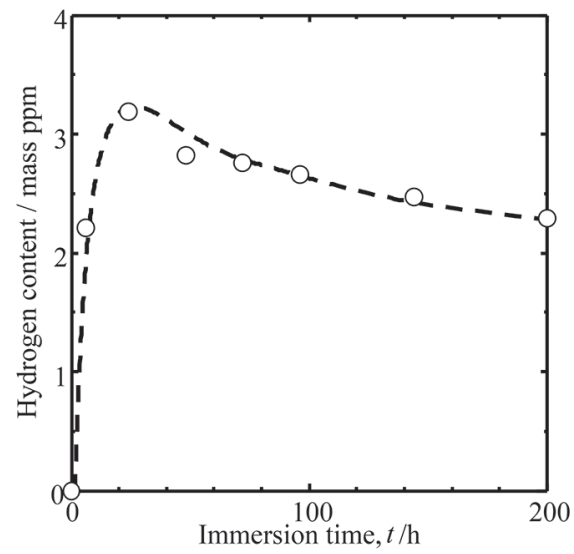

Fig. 8 Hydrogen contents of PC steel after immersion for 0 - 200 $\mathrm{h}$ in a 20 mass $\% \mathrm{NH}_{4} \mathrm{SCN}$ solution at a specific solution volume of $20 \mathrm{ml} / \mathrm{cm}^{2}$ at $50^{\circ} \mathrm{C}$ 
Table 1 Calculated solution pH on Eq.3 and measured solution $\mathrm{pH}$ as a function of the immerd time. Test conditions: 20 mass $\% \mathrm{NH}_{4} \mathrm{SCN}$ solution, $50^{\circ} \mathrm{C}$ and $\mathrm{N}_{2}$ deaeration.

\begin{tabular}{|c|c|c|}
\hline \multirow{2}{*}{$\begin{array}{l}\text { Immersion } \\
\text { time } / \mathrm{h}\end{array}$} & \multicolumn{2}{|c|}{ Solution $\mathrm{pH}$} \\
\cline { 2 - 3 } & Measured & Calculated \\
\hline 0 & 4.5 & 4.4 \\
\hline 6 & 6.1 & 6.0 \\
\hline 24 & 6.5 & 6.3 \\
\hline
\end{tabular}

基づき説明することができる ${ }^{25)}$.

FIP 試験中の溶液 $\mathrm{pH}$ の挙動の解明に基づき, 試験破断 時間に対する試験条件の作用がいくつか解明された ${ }^{31}$. 比液量の増加が破断時間を短縮する傾向があることは知 られていたが, その機構については明らかにされていな かった ${ }^{19)}$ 。（3) 式の反応に基づき比液量から溶液 $\mathrm{pH}$ の 計算が可能で実験結果とも整合した ${ }^{31)}$ 。比液量の増加は (3) 式の反応による $\mathrm{H}^{+}$と $\mathrm{NH}_{3}$ の影響を緩和し溶液 $\mathrm{pH}$ の 上昇を抑制する。（3) 式の反応は長時間保持され吸蔵水 素量が増加するため破断時間は短くなる．溶液 $\mathrm{pH}$ の上 昇速度を小さくするため比液量は大きい条件が望まし く, 複数の鋼材の評価試験では比液量を一定にした試験 が望ましい。試験後溶液の再使用も規格により扱いが分 かれていた ${ }^{19), 20)}$ 。試験後溶液は溶液 $\mathrm{pH}$ が高く $\mathrm{FeS}$ 皮膜 の析出に伴う (3) 式の反応の抑制が早期に起こり，鋼中 水素濃度が低下する，破断時間は長くなることから試験 後溶液の再使用は好ましくない ${ }^{31)}$ 。また, 従来解明され ていなかった温度, 溶液濃度, 溶存酸素などの試験条件 の影響も明らかにした ${ }^{30), 31)}$.

以上の知見を反映して試験条件の共通化が行われた. 同一 PC 鋼材を 4 機関で各 10〜16 本の試験を実施した 結果として, 平均破断時間で $61 \sim 74 \mathrm{~h}$ が報告されて ${ }^{32)}$, 1 オーダー近い試験機関によるバラツキが大きく抑制さ れた。

\section{5 試験手順の標準化と活用}

試験手順を仕様書などで活用するには公的な試験規格 であることが望ましい. 2007 年から腐食防食学会で FIP 標準試験手順の原案策定が行われ，2010 年から FIP 試 験規格化小委員会 (主査 高井健一 上智大学教授)が発 足し FIP 標準試験手順の規格化が行われた ${ }^{32}$ 。産業界の 委員として電力, 通信のコンクリート柱ユーザーと, 鋼 材熱処理，鉄鋼の PC 鋼材メーカーが参画した.

本規格は, 2012 年に腐食防食学会規格「20\%チオシア ン酸アンモニウム溶液中での PC 鋼材の水素脆化試験方 法」JSCE S 1201 の水素脆化評価試験手順として発行さ れた ${ }^{32)}$. 国内の試験実施機関が保有する試験設備や運用 を考慮し，現在国内で流通している PC 鋼材を用いて試 験精度の向上を目的とした, 実験条件, 手順, 使用機器 について詳細な検討と規定を行っている.

本規格試験の再現性向上は繰返し試験数の減少による 試験負荷軽減と試験品質向上につながり，PC 鋼材など の品質管理へ適用が拡大している．特にコンクリート柱 については応力腐食割れに配慮した鋼材を使用するよう に規定されている ${ }^{15)}$. 本規格試験で短時間破断を示す $\mathrm{PC}$ 鋼材はコンクリート柱内でも短時間で破断すること
も示唆されている ${ }^{33)} . \mathrm{PC}$ 鋼材の製造者からコンクリー 卜柱の設備管理者にまで本規格試験が PC 鋼材の応力腐 食割れ試験として活用されている．特にコンクリート柱 の場合，使用される PC 鋼材の水素脆化感受性の評価に より, コンクリート柱自体の水素脆化に対する裕度の評 価が可能となる，このため，経年による設備更新ではな く水素脆化を考慮したリスクベースマネジメントや，コン クリート柱の設計情報や保全データと照合して柱の保全 や点検の精度向上にも寄与することが期待されている ${ }^{34)}$.

\section{6. 屋外鋼構造電力流通設備への取り組み}

\section{1 架空配電機材の腐食環境の定量評価}

コンクリート柱と同様に物量の多い機材は柱上変圧器 である．当社管内でも約 200 万台が設置されている，柱 上変圧器は需要家のニーズに応じて設置, 撤去, 交換さ れることから設置状態の面的な管理が重要となる．柱上 変圧器などの腐食リスクの把握を容易にし, 巡視や保全 の精度向上や負荷の軽減を目的として, 塩害地域に設置 された架空配電機材の腐食環境の定量評価や可視化が行 われている ${ }^{35)}$.

架空配電設備の腐食環境可視化のフローを Fig.9 に示 す. 対象地域内の腐食強度や環境因子を複数地点で計測 し, 腐食強度に対する多変量解析から地域内の腐食強度 の推定式を求める．得られた推定に基づく地域内の腐食 強度分布は, 実設備の経年劣化の状況とも対応している ことが確認されている ${ }^{35)}$ ．配電設備の保全は配電網に基 づくブロックごとに管理されており，腐食環境定量評価 に基づき地域内のブロックの管理方法を見直ことができ る。腐食環境の厳しいブロックは防食性に優れた機材を 配置し点検頻度を増加し, 腐食環境が軽微なブロックは 保全負荷を軽減することが可能である ${ }^{36)}$.

架空配電設備の腐食環境定量評価で重要な点は目的変 数の設定である. 目的変数は定量的で対象機材の腐食を 模擬した指標が望ましく，鋼材や亜鉛めっきの年間の腐 食減量を用いている。腐食減量の測定は, Fig.10に示す ように配電設備の設置位置での暴露試験により計測して いる ${ }^{37)}$ 。腐食センサーや環境センサーなどの計器測定に 比較して計測に必要な作業負荷が小さく, 計測環境での 適性の検証が不要であるという利点がある ${ }^{37}$.

同種の設備は全国で使用され，電力システムの変化に 伴い仕様の共通化などが要求される。多様な屋外環境に 対応した設備仕様を検討するために, 架空配電機材を対

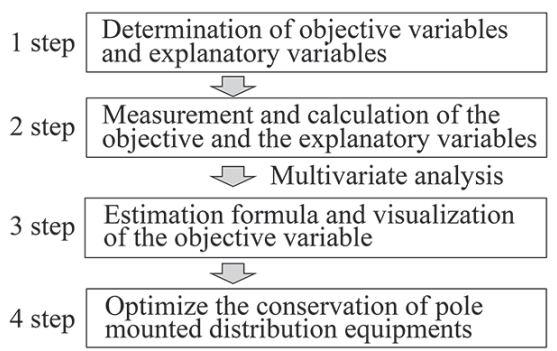

Fig. 9 Procedure of corrosive environment quantitative evaluation of power distribution equipment. 


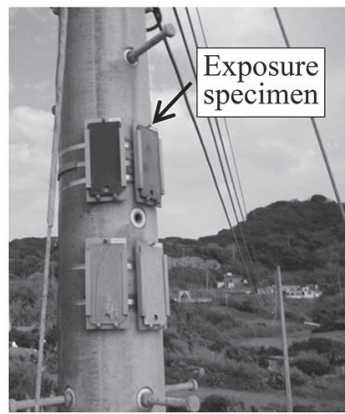

Fig. 10 Exposure test at the installation location of the pole mounted power distribution equipment.

象とした全電力での劣化環境の定量化取り組みが行われ た ${ }^{38)}$. 架空配電機材の劣化環境は，腐食だけではなく電 気的絶縁を損ないトラッキングを生じる塩污損環境，高 電圧で絶縁破壊を生じる雷など多様である，腐食に関す る取り組みは, 腐食防食学会内に電力流通設備小委員会 を組織して対応している，全電力での架空配電機材設置 環境での Fig.10に示した配電設備の設置位置での暴露試 験による腐食環境指標の作成や，各種防錆材料の長期性 能評価を行っている ${ }^{38)}$.

\section{2 塗装防錆の課題}

屋外の鋼構造設備に沉用的に使用される塗装は防錆寿 命の推定が難しい防錆技術である．重要設備に用いる塗 膜の長期防錆寿命は，下塗りの防食性能を保護する上塗 りの耐候性により主に担保される. 上塗り塗膜の選定の 拠り所となる規格は重要である。耐候性に優れた上塗り については，ふっ素樹脂系塗膜に代表される JIS K 5659 上塗り 1 級の規格がある ${ }^{39)}$. 1 級に要求される主な耐候 性能は, JIS K 5600-7-7 促進耐候性および促進耐光性 (キ セノンランプ法) に定めるXenon 照射 $2000 \mathrm{~h}$ で塗膜の光 沢保持率が $80 \%$ 以上である。この規格は 2008 年に改訂 されており, 改訂前はふっ素樹脂と異なるシリコン系樹 脂, ポリウレタン系樹脂も規定され，樹脂系ごとに性能 や成分の含有量などが規定されていた，改定後は樹脂組 成などの仕様に関する規定がなくなり，促進試験に依存 した性能規定の規格となっている.Xenon 照射試験と実 環境での耐候性が異なる塗膜では誤った認定を与えるこ ととなる．実際に 1 級に認定されている商用塗料でも製 品により実環境での耐候性能に大きな差異が認められる ことが報告されている ${ }^{40)}$.

塗膜は主に樹脂と顔料から構成される．JIS 規格は主 としてXenon 照射による樹脂の耐候性評価に基づき決定 され，顔料の耐候性に関する評価は反映されていない。 顔料に用いられる酸化チタンは屋外で光触媒活性を示し 樹脂を分解して塗膜の光沢を低下させることがアルキド メラミン系の自動車用塗膜で報告されている ${ }^{41)}$. 顔料に 用いられる酸化チタンは屋外で光触媒活性を示し樹脂を 分解して塗膜の光沢を低下させることから，顔料表面に 活性を抑制する処理が施されている．重防食用の耐候性 塗膜の暴露試験後の表面形態の例を Fig.11に示す. $1 \mu \mathrm{m}$ 程度の酸化チタン顔料の周囲でクレーター状に樹脂が消 失し, 自動車用塗膜と同様の事象が確認されている ${ }^{42)}$.

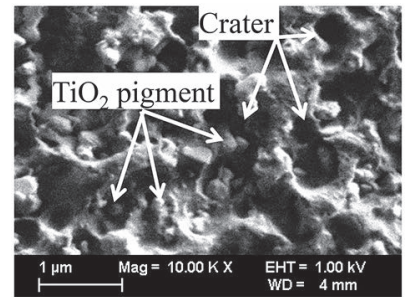

Fig. 11 Surface morphology after weathering test of heavy duty corrosion-proof coat for weather resistance.

規格に定めた樹脂の耐候性を評価するXenon 照射試験は 耐候性塗膜の実環境での性能評価に充分対応できていな い. 電力設備の管理者は必ずしも塗料の専門家ではなく 基本的に公的規格に基づく塗料選定を行う。このため JIS K 5659 で用いられる促進耐候性試験を補完する試験 法が必要とされている. 現在, 重防食用耐候性塗膜の顔 料の品質に着目した新たな塗膜の耐候性試験法が腐食防 食学会建設小委員会内の WG $(\mathrm{HP}$ 試験耐候性 WG 主査

貝沼重信 九州大学准教授)で検討されている.

この促進試験法は, 自動車用塗膜への適用を目的とし て開発され過酸化水素(Hydrogen Peroxide)の間欠噴霧 とXenon 照射を併用して実環境で生じる顔料起因の光触 媒劣化を加速するものである ${ }^{41)}$. 重防食用塗膜について も検討が行われ HP-Xe 試験と称されている ${ }^{43)}$. HP-Xe 試験は高耐候性塗膜の実環境での顔料に起因する耐候性 低下と良い相関を示す ${ }^{42)}$. HP-Xe 試験は塗料採用時の 活用や学会での規格化が期待される.

\section{7. まと め}

電柱の設備保全に関連する $\mathrm{PC}$ 鋼材の水素脆化感受性 評価を中心に電力流通設備における腐食防食課題への取 り組みや最近の腐食防食課題を取り巻く環境の変化につ いて紹介した，設備の高経年化が進むにつれ，当初予期 しなかった腐食問題に保全方策を含めて対応するケース が増えてくるものと予想される，電力流通設備における 設備寿命や損傷リスクに関する産学連携した取り組みが 今後も期待される。本稿が電力流通設備の腐食防食技術 の将来を考える一助となれば幸いである。

\section{謝辞}

電力流通設備の水素脆化や防食経年劣化対策に多くの 学識者, 材料, 機材, 通信, 電力会社の皆様のご理解と ご協力をいただきました，特に，早稲田大学 酒井潤一 教授, 上智大学 高井健一教授には大変お世話になりま した。この場を借りて厚く御礼を申し上げます。

\section{参 考 文 献}

1) H. Yamauchi and A. Sawa, Maruwakari denryoku system kaikaku key word 360, Jpn. Electric Association News paper Division (2015).

2) M. Ichiba, T. Hirasaki, T. Tsuboi and S. Tsukao, Proc. 52th Jpn.Conf. Materials and Environments, JSCE, p.87 (2005).

3) M. Ishikawa, M. Ichiba, D. Akiba, M. Kamioka and Y. Tsuneishi, Proc. Annual Conf. Fundamentals and Materials Soc., IEE Japan, p.188 (2008).

4) M. Ishikawa, M. Ichiba, A. Koike, N. Kamata and K. Itoi, 
Proc. 55th Jpn.Conf. Materials and Environments, JSCE, p.301 (2008).

5) Y. Niidome, M. Ichiba, Y. Ueki, M. Ando and S. Tsujikawa, Proc. 55th Jpn.Conf. Materials and Environments, JSCE, p.347 (2008)

6) M. Ishikawa, A. Koike, M. Ichiba and K. Itoi, Proc. JSCE Materials and Environments 2009, JSCE, p.195 (2009).

7) M. Ichiba and K. Takahashi, Proc. JSCE Materials and Environments 2010, JSCE, p.71 (2010).

8) M. Ichiba and K. Okamura, Proc. JSCE Materials and Environments 2010, JSCE, p.75 (2010).

9) Y. Hayakawa and M. Ichiba, Proc. 57th Jpn.Conf. Materials and Environments, JSCE, p.259 (2010).

10) M. Ichiba, T. Takaoka, K. Kasahara and W. Oshikawa Proc. JSCE Materials and Environments 2013, JSCE, p.125 (2013).

11) A. Kataoka, M. Ichiba and M. Miyata, Proc. JSCE Materials and Environments 2014, JSCE, p.161 (2014).

12) M. Ichiba, K. Watanabe, T. Suzuki, T. Ishii, N. Tanaka and K. Iwanaga, Proc. JSCE Materials and Environments 2015, JSCE, p.37 (2015).

13) Konkuri-to po-ru handobukku, Railway Electrification Committee (1958).

14) T. Uomoto and Y. Takada, Journal of Materials, Concrete Structures and Pavements(V), Jpn. Soc. of Civil Eng., 17 [451] p.119 (1992).

15) JIS A 5373:2016, Precast prestressed concrete products, JIS (2016).

16) K. Takayama and J. Seki, NTT Shisetsu, Nippon Telegraph and Telephone Corporation, 41 [2] 26 (1989).

17) S. Matsuyama, Okurehakai, Nikkan Kogyo Shimbun Ltd. (1989).

18) Y. Miyata, Proc. 102nd Symposium, JSCE, p.53 (1994).

19) FIP WG, Technical Report "Report on Prestressing Steel:5. Stress corrosion cracking resistance test for prestressing tendons", FIP (1980).

20) ISO $15630-3$, Steel for the reinforcement and prestressing of concrete - Test methods (2002).

21) K. Takai, S. Takagi and T. Omura, Bull. Iron Steel Inst. Jpn., 19 [12] p.911(2014).

22) M. Nagumo, Suisozeisei no kiso, Uchida rokakuho, p.142 (2008).

23) M. Elices, L. Caballero, A. Valiente, J. Ruiz and A. Martin, Corrosion, 64 [2] p.164 (2008).

24) M. Ichiba, E. Nakamura and H. Miyamoto, Proc. 170th Symposium, JSCE, p.14 (2010).

25) M. Ichiba, Y. Niidome, S. Nakamura and J. Sakai, Zairyoto-Kankyo, 62, p.289 (2013).

26) M. Ichiba, K. Abe and J. Sakai, Zairyo-to-Kankyo, 64, p.244
(2015)

27) The Chemical Society of Japan, Kagakubinran kisohen II 5th edition, Maruzen, p. II -313(2004).

28) M. Ichiba, J. Sakai, T. Doshida and K. Takai, Scr. Mater. 102, p.59 (2015)

29) T. Doshida, K. Takai and M. Ichiba, Zairyo-to-Kankyo, 61, p.249 (2012)

30) M. Ichiba, K. Takai and J. Sakai, Zairyo-to-Kankyo, 65, p.67 (2016)

31) M. Ichiba, K. Takai and J. Sakai, ISIJ, 56, p.397 (2016).

32) JSCE S 1201, Method of hydrogen embrittlement test for steel for prestressed concrete in a $20 \%$ ammonium thiocyanate solution, JSCE (2012).

33) M. Ichiba, A. Kataoka and Y. Niidome, Proc. Annual Conf. Fundamentals and Materials Soc., IEE Japan, p.47 (2014).

34) Genba repo-to No.7, Tokyo Electric Power Company Holdings, Inc., < https://www4.tepco.co.jp/challenge/ cost_reductionreport_07.html $>$ [Accessed 29 August 2016].

35) M. Ichiba, A. Kataoka, T. Takaoka and H. Kase, Proc. JSCE Materials and Environments 2013, JSCE, p.135 (2013).

36) A. Kataoka, M. Ichiba, T. Takaoka, H. Kase and T. Uduki, Proc. JSCE Materials and Environments 2013, JSCE, p.193, (2013).

37) Y. Ueki, M. Ichiba, T. Usui, K. Ito and T. Tujikawa, Proc. 54th Jpn.Conf. Materials and Environments, JSCE, p.123 (2007).

38) K. Michisita et al., Quantitative Evaluation of Deterioration Environment for Power distribution equipments, Electric Technology Research Association, 69 [3] 130 (2013).

39) JIS K 5659, Long durable paints for steel structures, JIS (2008).

40) M. Saito, S. Moriya, H. Hamanura, H. Goto, Y. Naito, M. Yamamoto and M. Fujishiro, Proc. 31st Forum on Corrosion-Proof Painting for Steel Structures, JSSC, 31, p.133(2008).

41) K. Mori, T. Natita, K. Tachi and S. Umemura, J. Materials Life Soc., Materials life soc, Japan, 13 [4] p.180 (2001).

42) M. Ichiba, K. Harada, K. Kasahara, O. Ikeda and T Takayanagi, Proc. 57th Jpn.Conf. Materials and Environments, JSCE p.334 (2010).

43) M. Ichiba, J. Ozaki, T. Suzuki, K. Kasahara and T. Takayanagi, Proc. 61th Jpn.Conf. Materials and Environments, JSCE, p.145 (2014).

（2016 年 9 月 1 日受理

近年，電気事業の体制は大きな変貌を遂げつつある。米国の電気事業制度を模して戦後構築された垂直 統合型の電力供給体制は, 送電線の広域運用, 小売全面自由化, 発送電分離といった歴史的なパラダイム シフトを迎えている。この動きは電力流通設備の腐食防食課題へも影響し, 設備の保全, 寿命や損傷リス クに関する取り組みが重要となっている，本稿では電力流通設備で設備量の大きな電柱や屋外鋼構造設備 の腐食防食課題を例に，PC 鋼材や塗料の性能評価試験への取り組みや学協会との連携について示す.

キーワード 電力流通設備 (配電設備), コンクリート柱, 水素脆化, FIP, JSCE S 1201, チオシアン 酸アンモニウム，腐食，柱上変圧器，PC 鋼材，塩害，暴露試験，腐食マップ，重防食塗装 